\title{
The regulatory roles of long non-coding RNAs in the development of chemoresistance in breast cancer
}

\author{
Akshay Malhotra ${ }^{1}$, Manju Jain ${ }^{1}$, Hridayesh Prakash ${ }^{2}$, Karen M. Vasquez ${ }^{3}$ and Aklank \\ Jain 4 \\ ${ }^{1}$ Centre for Biochemistry and Microbial Sciences, Central University of Punjab, Bathinda, Punjab, India \\ ${ }^{2}$ Laboratory of Translational Medicine, School of Life Sciences, University of Hyderabad, Gachibowli, Hyderabad, India \\ ${ }^{3}$ Division of Pharmacology and Toxicology, College of Pharmacy, The University of Texas at Austin, Dell Pediatric Research \\ Institute, TX, USA \\ ${ }^{4}$ Centre for Animal Sciences, Central University of Punjab, Bathinda, Punjab, India \\ Correspondence to: Aklank Jain, email: aklankjain@gmail.com
}

Keywords: breast cancer; chemoresistance; long non-coding RNA; IncRNA; drug resistance

Received: June 06, $2017 \quad$ Accepted: October 13, $2017 \quad$ Published: November 08, 2017

Copyright: Malhotra et al. This is an open-access article distributed under the terms of the Creative Commons Attribution License 3.0 (CC BY 3.0), which permits unrestricted use, distribution, and reproduction in any medium, provided the original author and source are credited.

\section{ABSTRACT}

Chemoresistance is one of the major hurdles in the treatment of breast cancer, which limits the effect of both targeted and conventional therapies in clinical settings. Therefore, understanding the mechanisms underpinning resistance is paramount for developing strategies to circumvent resistance in breast cancer patients. Several published reports have indicated that IncRNAs play a dynamic role in the regulation of both intrinsic and acquired chemoresistance through a variety of mechanisms that endow cells with a drug-resistant phenotype. Although a number of IncRNAs have been implicated in chemoresistance of breast cancer, their mechanistic roles have not been systematically reviewed. Thus, here we present a detailed review on the latest research findings and discoveries on the mechanisms of acquisition of chemoresistance in breast cancer related to IncRNAs, and how IncRNAs take part in various cancer signalling pathways involved in breast cancer cells. Knowledge obtained from this review could assist in the development of new strategies to avoid or reverse drug resistance in breast cancer chemotherapy.

\section{INTRODUCTION}

Despite advances in early diagnosis, therapy and surgery, breast cancer is still the leading cause of cancer related death in women worldwide $[1,2]$. Although various chemotherapeutic agents such as docetaxel, tamoxifen, cisplatin, carboplatin, doxorubicin, gemcitabine, mitoxantrone etc. have improved the overall survival and quality of life for patients, the 5 year survival of stage IV breast cancer patients is still very low $(\sim 20 \%)$ for most estrogen receptor (ER) positive/progesterone receptor (PR) negative subtypes [3]. This may be in part due to increases in intrinsic (e.g. stromal fibrosis and interactions between cell surface integrins and extracellular matrix components) and extrinsic factors (e.g. the expression of one or more energy-dependent transporters which eject chemotherapeutic drugs from cells) that promote resistance to chemotherapy in breast cancer cells [4]. Thus, there is an urgent need to better understand the mechanisms associated with chemoresistance in breast cancer to aid the development of improved therapies for the treatment of breast cancer.

The advancement in large-scale whole genome sequencing technologies suggests that less than $2 \%$ of the human genome encodes for proteins, whereas much of the remaining genome is transcribed into non-coding RNAs (ncRNAs) $[5,6]$. Such non-coding RNAs are transcribed into a large variety of regulatory RNAs, including piwiinteracting RNAs (piRNAs), microRNAs (miRNAs), small-interfering RNAs (siRNAs), circular RNAs (circRNAs), small Cajal body-specific RNAs (scaRNAs), small nucleolar RNAs (snoRNAs), transfer RNAs (tRNAs), ribosomal RNAs (rRNAs) and long non-coding RNAs (lncRNAs) [7, 8]. Among these ncRNAs, lncRNAs 
(i.e. lengths $>200$ nucleotides) are found to be important regulators of carcinogenesis [9]. Previous studies have provided evidence for their regulatory roles in facilitating carcinogenesis, invasion-metastasis, and chemoresistance in many cancers, as reviewed in [10]. Their roles in the pathogenesis of gallbladder [11] and lung cancers [5] have also been highlighted in recent reviews, along with their regulatory roles in a wide range of biological processes such as transcription, translation, RNA interference, epigenetic gene regulation, and cell-cycle control.

Recently, lncRNAs such as $\operatorname{lncRNA-ATB}$ [12], GAS5 [13, 14], HOTAIR [15], CCAT2 [16], H19 [17], BCAR4 [18], UCA1 [19-21], LncRNA-ROR [22] and LncRNA-ARA [23] have been implicated in resistance to chemotherapy in breast cancer patients (Table 1 and Figure 1). Though these lncRNAs have been implicated in resistance to chemotherapeutic agents used in the treatment of breast cancer, a comprehensive review is still missing. Thus, in this review, we discussed in detail the regulatory roles of various lncRNAs in contributing to chemoresistance in breast cancer therapy. The published work described has provided a better understanding of the mechanisms underlying the contribution of lncRNAs to chemoresistance, which may lay the foundation for the development of improved therapies for the treatment of breast cancer.

\section{Long non-coding RNA activated by TGF- $\beta$ (LncRNA-ATB)}

As the name suggests, TGF- $\beta$ regulates and activates the expression of LncRNA-ATB. TGF- $\beta$, a master regulator of EMT (epithelial-mesenchymal transition), alters gene expression of several oncogenes such as Zinc finger E-box-binding homeobox 1 (ZEB1), Zinc finger E-box-binding homeobox 2 (ZEB2) and Zinc finger 217 (ZNF217) that promote cellular proliferation, invasiveness, and resistance to apoptosis. $L n c-A T B$ is a non-adenylated 2 exon transcript, which stretches over $80 \mathrm{~kb}$ at chromosome 14q11.2 [24]. It has been shown to be significantly over-expressed in several human cancers such as hepatocellular carcinoma [25], colorectal [26, 27], prostate [28], and gastric cancers [29].

Approximately $25 \%$ of patients with metastatic HER2-amplified breast cancer, which is the leading cause of mortality in breast cancer patients, show resistance to trastuzumab based therapy $[12,30]$. Shi et al. (2015) found that $\ln C R N A-A T B$ was up-regulated by $\sim 2$-fold in breast cancer patients on trastuzumab therapy over other breast cancer patients, by using microarray analysis on breast cancer tissues of five trastuzumab-resistant (TR) breast cancer patients [12]. Similarly, they observed that TR human SKBR-3 breast cancer cells (TR SKBR3) expressed 2.5-fold more $\operatorname{lnc} R N A-A T B$ compared to wild-type SKBR-3 (WT SKBR-3) breast cancer cells. It was further observed by the authors that in the presence of trastuzumab, TR SKBR-3 cells had a greater rate of migration and invasion compared to WT SKBR-3 cells, and showed lower apoptotic rates in the presence of trastuzumab [12]. Moreover, down-regulation of $\operatorname{lnc} R N A$ $A T B$ by shRNA-ATB significantly decreased the migration and invasion capacity of the TR SKBR-3 cells, which suggested that $\ln c-A T B$ promoted trastuzumab resistance by facilitating the invasive and EMT characteristics

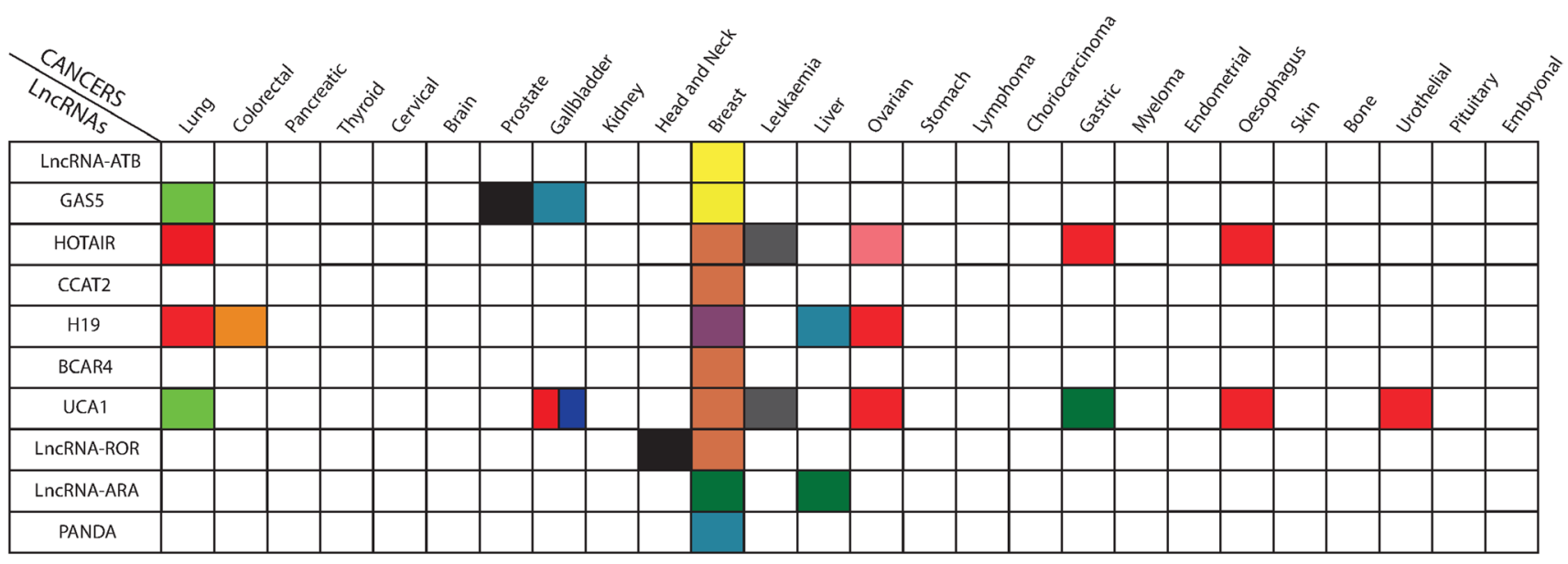

$\begin{array}{|lllll|}\square \text { Trastuzumab } & \square \text { Imatinib } & \square \text { Tamoxifen } & \square \text { Doxorubicin } & \square \text { Adriamycin } \\ \square \text { Gefitinib } & \square \text { Paclitaxel } & \square \text { Carboplatin } & \square \text { Methotrexate } & \text { Unknown } \\ \begin{array}{l}\text { Cisplatin } \\ \text { Gemciitabine }\end{array} & & & \end{array}$

Figure 1: Altered expression level of IncRNAs dysregulates chemotherapy treatment in various human cancers. The shaded squares represent a relationship between lncRNAs (on the left) varied chemotherapy response in different cancer types (on the top) in the Figure. 
Table 1: Breast cancer-associated long non-coding RNAs, their reported biological functions in drug resistance and the affected pathways

\begin{tabular}{|c|c|c|c|c|c|c|c|c|c|c|}
\hline S.No. & LncRNA & $\begin{array}{l}\text { Genomic } \\
\text { Location }\end{array}$ & $\begin{array}{l}\text { Mean fold } \\
\text { change in } \\
\text { expression } \\
\text { compared to } \\
\text { controls }\end{array}$ & $\begin{array}{l}\text { Resistance } \\
\text { against }\end{array}$ & Property & $\begin{array}{l}\text { Validation } \\
\text { Methods }\end{array}$ & $\begin{array}{c}\text { Biological } \\
\text { significance }\end{array}$ & $\begin{array}{c}\text { Genes/Proteins/ } \\
\text { Pathways affected }\end{array}$ & Cell lines & References \\
\hline 1) & $\begin{array}{l}\text { LncRNA- } \\
\text { ATB }\end{array}$ & $14 q 11.2$ & $\sim \uparrow 2.0$ fold & Trastuzumab & Oncogenic & $\begin{array}{l}\text { Microarray } \\
\text { analysis; qRT- } \\
\text { PCR }\end{array}$ & $\begin{array}{l}\text { Promotes cell } \\
\text { proliferation, } \\
\text { EMT, invasion and } \\
\text { metastasis }\end{array}$ & 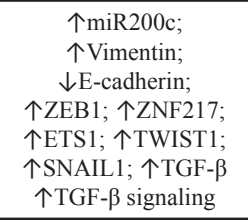 & SKBR3 & [12] \\
\hline 2) & GAS5 & 1q25.1 & $\sim \downarrow 2.7$ fold & Trastuzumab & $\begin{array}{l}\text { Tumor } \\
\text { suppressor }\end{array}$ & $\begin{array}{l}\text { Microarray } \\
\text { analysis; } \\
\text { qPCR; } \\
\text { Western blot } \\
\text { analysis }\end{array}$ & $\begin{array}{l}\text { Inhibits cell } \\
\text { proliferation and } \\
\text { tumor growth }\end{array}$ & 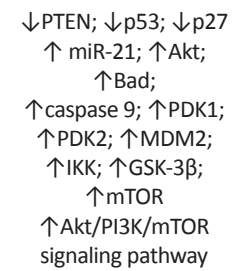 & SKBR3 & {$[13,14]$} \\
\hline 3) & HOTAIR & $12 \mathrm{q} 13.13$ & $\sim \uparrow 4.0$ fold & Tamoxifen & Oncogenic & $\begin{array}{l}\text { Microarray } \\
\text { analysis; } \\
\text { qPCR; } \\
\text { Western blot } \\
\text { analysis }\end{array}$ & $\begin{array}{l}\text { Promotes cell } \\
\text { proliferation, } \\
\text { invasion and } \\
\text { metastasis }\end{array}$ & $\begin{array}{c}\text { 个 EZH2; } \uparrow \text { estrogen } \\
\text { receptor protein; } \\
\uparrow \text { GREB1 gene; } \uparrow T F F 1 \\
\text { gene; and } \\
\uparrow c-M Y C \text { gene }\end{array}$ & $\begin{array}{c}\text { MCF-7 } \\
\text { and T47D }\end{array}$ & [15] \\
\hline 4) & CCAT2 & $8 \mathrm{q} 24.21$ & $\sim \uparrow 6.5$ fold & Tamoxifen & Oncogenic & $\begin{array}{l}\text { Microarray } \\
\text { analysis; qRT- } \\
\text { PCR; Western } \\
\text { blot analysis }\end{array}$ & $\begin{array}{l}\text { Promotes cell } \\
\text { proliferation; } \\
\text { tumorigenesis and } \\
\text { inhibits apoptosis }\end{array}$ & $\begin{array}{c}\text { 个ERK; } \\
\text { 个 ERK/MAPK signaling } \\
\text { pathway }\end{array}$ & $\begin{array}{c}\text { MCF-7 } \\
\text { and T47D }\end{array}$ & [16] \\
\hline 5) & H19 & $11 \mathrm{p} 15.5$ & $\sim \uparrow 3.0$ fold & Paclitaxel & Oncogenic & $\begin{array}{l}\text { qRT-PCR; } \\
\text { Western blot } \\
\text { analysis; ChIP } \\
\text { assay }\end{array}$ & $\begin{array}{c}\text { Promotes } \\
\text { tumorigenesis, } \\
\text { metastasis and } \\
\text { inhibits apoptosis }\end{array}$ & $\begin{array}{c}\downarrow \text { BIK gene; } \\
\uparrow E Z H 2 ; \downarrow \text { NOVA gene }\end{array}$ & $\begin{array}{l}\text { MCF-7 } \\
\text { and ZR- } \\
75-1\end{array}$ & [17] \\
\hline 6) & BCAR4 & $16 \mathrm{p} 13.13$ & $\begin{array}{c}\text { Not } \\
\text { determined }\end{array}$ & Tamoxifen & Oncogenic & $\begin{array}{l}\text { qRT-PCR; } \\
\text { Western blot } \\
\text { analysis }\end{array}$ & $\begin{array}{l}\text { Promotes cell } \\
\text { proliferation, } \\
\text { metastasis } \\
\text { and tumor } \\
\text { aggressiveness }\end{array}$ & 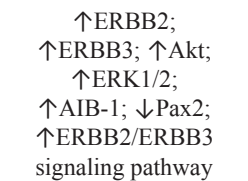 & ZR-75-1 & [18] \\
\hline 7) & UCA1 & $19 \mathrm{q} 13.12$ & $\sim \uparrow 20.0$ fold & Tamoxifen & Oncogenic & $\begin{array}{l}\text { qRT-PCR; } \\
\text { Western blot } \\
\text { analysis }\end{array}$ & $\begin{array}{l}\text { Promotes cell } \\
\text { proliferation, } \\
\text { tumorigenesis and } \\
\text { Inhibits apoptosis }\end{array}$ & $\begin{array}{c}\downarrow \text { miR-143; } \\
\downarrow \text { caspase 3; } \\
\downarrow \text { miR-18a; } \\
\downarrow \text { p27; } \\
\uparrow A k t ; \uparrow m T O R ; \\
\uparrow A k t / m T O R \text { signaling } \\
\text { pathway; } \\
\uparrow \text { wnt/B-catenin } \\
\text { pathway }\end{array}$ & $\begin{array}{l}\text { MCF-7; } \\
\text { LCC2; } \\
\text { LCC9; } \\
\text { BT474; } \\
\text { T47D }\end{array}$ & $\begin{array}{l}{[19,20,} \\
21]\end{array}$ \\
\hline 8) & $\begin{array}{l}\text { LncRNA- } \\
\text { ROR }\end{array}$ & $18 \mathrm{q} 21.31$ & $\sim \uparrow 7.0$ fold & Tamoxifen & Oncogenic & $\begin{array}{l}\text { qRT-PCR; } \\
\text { Western blot } \\
\text { analysis }\end{array}$ & $\begin{array}{l}\text { Promotes cell } \\
\text { proliferation and } \\
\text { invasion }\end{array}$ & $\begin{array}{l}\text { 个ZEB1; } \text { 个ZEB2; } \\
\text { 个vimentin; } \\
\downarrow \text { miR-205-5p; } \\
\downarrow \text { E-cadherin }\end{array}$ & $\begin{array}{c}\text { TR5; } \\
\text { MCF-7; } \\
\text { MDA- } \\
\text { MB-231 }\end{array}$ & [22] \\
\hline 9) & $\begin{array}{l}\text { LncRNA- } \\
\text { ARA }\end{array}$ & $\mathrm{Xq} 23$ & $\sim \uparrow 4.0$ fold & Adriamycin & Oncogenic & $\begin{array}{l}\text { qRT-PCR; } \\
\text { Microarray } \\
\text { analysis }\end{array}$ & $\begin{array}{l}\text { Promotes cell } \\
\text { proliferation; } \\
\text { migration and } \\
\text { inhibits apoptosis } \\
\text { and cell cycle } \\
\text { arrest }\end{array}$ & 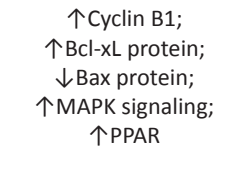 & MCF-7 & [23] \\
\hline
\end{tabular}

of these breast cancer cells. Earlier reports suggested that $\ln c R N A-A T B$ functions as a competing endogenous RNA (ceRNA) and competes with miR-200c binding sites. miR-200c has been reported to repress EMT and tumor invasion by targeting the 3'UTR of the ZEB1 and ZNF217 genes [31] (Figure 2). The authors determined the relative expression levels of miR-200c and $\operatorname{lncRNA}$ -
$A T B$ in breast cancer cells by performing microarray experiments and found that the expression level of miR200c was significantly downregulated in both TR breast cancer patients ( 2-fold) and TR SKBR-3 cells (2.5-fold) compared to their respective control, while lnc-ATB levels were increased. Further, by luciferase assays, the authors demonstrated that ectopic expression of lncRNA-ATB 
in TR SKBR-3 cells decreased miR-200c expression; whereas, silencing of lncRNA-ATB increased miR-200c expression. This result implied that $\operatorname{lnc} R N A-A T B$ binds to miR-200c and inversely correlates with its expression in TR SKBR-3 cells. LncRNA-ATB shares a regulatory miR-200c sequence within ZEB1 and ZNF217, and it was found that up-regulation of $\ln C R N A-A T B$ led to an increase in the expression of ZNF217 and ZEB1 at both the mRNA and protein levels in TR SKBR-3 cells [12]. It was further observed that the up-regulation of ZEB1 and ZNF217 by lnc-ATB further augmented the EMT effects in breast cancer cells (Figure 2). ZEB1, a key mediator of TGF- $\beta$ signaling and EMT regulatory pathways, directly suppresses miR-200c by targeting at least two highly conserved ZEB1-binding sequences that are located within the putative promoter; hence over-expression of ZEB1 leads to inhibition of miR-200c promoter activity (Figure 2). Moreover, enhanced TGF- $\beta$ signaling upregulates ZEB1 expression levels, and ZNF217 acts as an enhancer of TGF- $\beta$, and transcriptionally activates TGF- $\beta 2$ and TGF- $\beta 3$ in an autocrine loop $[9,32]$ (Figure 2).
Taken together, the findings above suggest that a high level of $\ln c R N A-A T B$ correlated with trastuzumab resistance in breast cancer patients, and it has pleiotropic effects on breast cancer cell invasion and trastuzumab resistance. Thus, it might be considered as an effective target molecule for anti-metastasis and reversal of trastuzumab resistance therapies for breast cancer patients.

\section{Growth arrest specific transcript (GAS5)}

GAS5 is a non-protein coding gene, which spans $\sim 7.0 \mathrm{~kb}$ on chromosome 1q25.1 and comprises a large number of small nucleolar RNAs (snoRNAs) [33]. It contains $10 \mathrm{C} / \mathrm{D}$ box snoRNAs, which are associated with methylation as well as 12 weakly conserved exons that are located within highly conserved introns, along with a $5^{\prime}$-terminal oligopyrimidine tract [33]. In humans, the GAS5 gene is expressed ubiquitously in many cell types and plays an important role in tumorigenesis [34]. Several studies have demonstrated that GAS5 is down-regulated in gastric [35], glioma [36], stomach [37], lung [38],

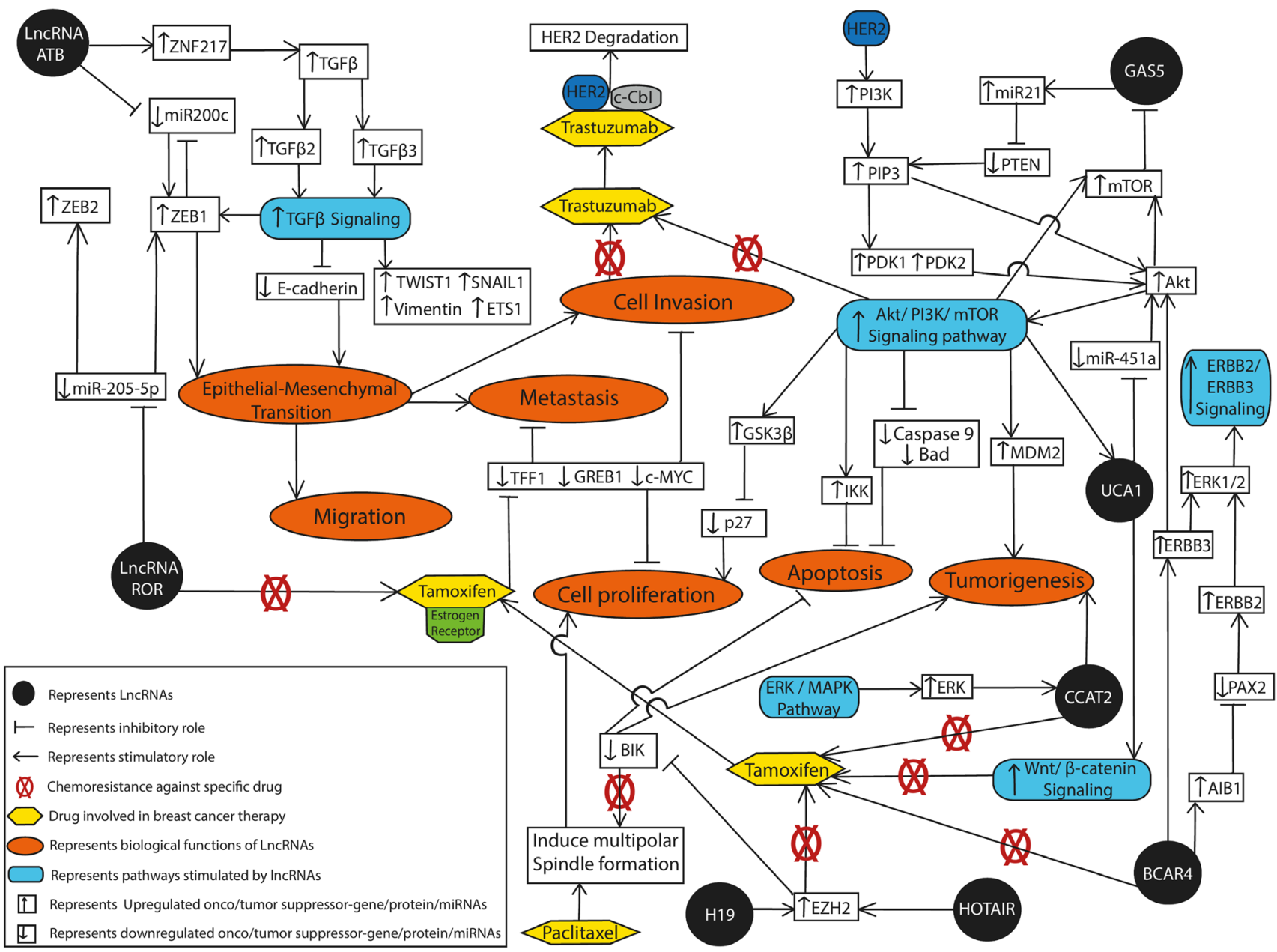

Figure 2: Regulatory networks of various IncRNAs associated with drug resistance involved in the pathogenesis of breast cancer. The schematic diagram depicts the putative cellular roles of IncRNAs in the upregulation (upward arrows) or downregulation (downward arrows) of gene products in various cellular events involved in breast cancer pathogenesis. 
cervical [39], liver [40], gallbladder [41], pancreatic [42], prostate [43] and breast cancer [13]. In breast cancer, GAS5 expression was found to be significantly downregulated ( 2.7 -fold) in cancerous tissues in breast relative to surrounding non-cancerous tissue, and this reduced expression of $G A S 5$ was correlated with advanced TumorNode-Metastasis (TNM) stage and lower rates of survival in these patients [13]. Moreover, down-regulation of GAS5 expression is also associated with chemoresistance in lung (gefitinib) [38], gall bladder (doxorubicin) [44] breast (trastuzumab) [13] and in prostate cancers [45] (Figure 1 ).

Recently, Li et al. (2016) observed that GAS5 expression was significantly down-regulated ( $\sim 2.7$-fold $)$ in trastuzumab-resistant TR SKBR-3 cells and trastuzumabresistant breast cancer patients $(n=86)$ compared to non-tumor tissues, as assessed by real-time PCR [13]. Furthermore, they found that GAS5 expression was also down-regulated ( 2.0-fold) in HER-2 positive breast cancer samples $(n=20)$ relative to matched noncancerous tissue samples [10]. Toward a better understanding of the mechanistic involvement of GAS5 in trastuzumab-resistant breast cancer cells, they found that knockdown of GAS5 led to cell proliferation and tumor growth in SKBR3 trastuzumab-resistant cancer cells. Knockdown of GAS5 in trastuzumab-resistant cells also led to decreased phosphatase and tensin homolog (PTEN) expression. PTEN is ubiquitously expressed in humans, where it dephosphorylates phosphatidylinositol-3,4,5-triphosphate (PIP3) and negatively regulates the AKT/PI3K pathway; a signaling pathway known to increase drug sensitivity, including sensitivity of trastuzumab (Figure 2). Further, it was found that GAS5 functions as a molecular sponge for miR-21, which is known to promote tumor proliferation and invasion by down-regulating PTEN expression (Figure $2)$. These findings suggest that the down-regulation of GAS5 can lead to de-repression of the PTEN gene in trastuzumab-resistant breast cancer cells [10]. Thus, GAS5 may be explored as a prognostic and diagnostic molecule in trastuzumab-resistant breast cancer patients.

\section{HOX transcript antisense RNA (HOTAIR)}

HOTAIR, a $2.2 \mathrm{~kb}$ transcript localized on the antisense strand of the Homeobox C (HOXC) locus on chromosome 12q.13.13, has been identified as a cancer-associated IncRNA [5]. It interacts with the Polycomb Repressive Complex 2 (PRC2), which induces histone $\mathrm{H} 3$ lysine-27 trimethylation at the Homeobox D (HOD) domain, which down-regulates the expression of a number of genes that can result in tumorigenesis and metastasis [46]. This lncRNA was found to be up-regulated in various cancer types, such as ovarian [47], gastric [48], prostate [49], kidney [50], cervical [51], ovarian [52], bladder [53], lung [54] and breast [46]. Over-expression of HOTAIR can result in chemoresistance against certain drugs in ovarian (carboplastin) [47, 55], gastric (cisplatin) [56], lung (cisplatin) [57, 58], leukemia (imatinib) [59], esophagus (cisplatin) [60], and breast (tamoxifen) cancers [15] (Figure 1).

Tamoxifen is among the most commonly used chemotherapeutic agents in the treatment of breast cancer, specifically estrogen receptor (ER)-positive cases, which account for more than $70 \%$ of all breast cancers [61]. However, ER-positive patients with metastatic disease respond poorly to tamoxifen therapy, and often with increasing dose and time develop resistance to tamoxifen [62]. In an effort to better understand the cause of tamoxifen resistance in breast cancer therapy, Xue et al. (2016), found that HOTAIR accumlated in nuclei and its expression was increased in tamoxifen-resistant breast tumor cells compared to primary, hormone-naïve tumor cells [15]. When the estrogen receptor alpha positive $(\mathrm{ER}+)$ human breast cancer cell lines (MCF7 and T47D) were treated with tamoxifen, HOTAIR levels increased over that of untreated cells [12]. This increase in HOTAIR levels correlated with a reduction in the expression of the growth regulation by estrogen in breast cancer 1 (GREB1) gene, a known ER-induced gene. Moreover, the authors observed a direct interaction of HOTAIR with nuclear hormone receptor ER, even under estrogendepleted conditions. In the presence of estrogen, it was found that HOTAIR expression decreased in a timedependent manner in both MCF and T47D cells, while GREB1 expression increased. Furthermore, the levels of HOTAIR were considerably restored in breast cancer cells following hormone deprivation, whereas GREB1 expression was lost [12]. To determine whether estrogen inhibited HOTAIR expression through direct ER binding to HOTAIR regulatory elements, the authors performed chromosome conformation capture experiments and found estrogen-induced DNA looping between the transcription start site of the HOTAIR gene and the ER-bound enhancer, which leads to repression of HOTAIR expression. HOTAIR possess an ER-binding site in a genomic region $\sim 14.5 \mathrm{kB}$ upstream of the transcriptional start site of the HOTAIR gene [63], which is typically occupied by H3K4me1 and H3K27ac modified histones, which normally upregulate gene expression. Thus, these results suggest that HOTAIR is repressed by estrogen and is therefore up-regulated following hormone deprivation and in tamoxifen-resistant breast cancer, as tamoxifen is known to compete with estrogen to inhibit estrogen-induced ER activities in mammary cells $[61,64]$.

Importantly, over-expression of HOTAIR resulted in increased ER protein levels in the nucleus even under hormone-starved conditions [12]. Thus, ER-induced genes were significantly up-regulated following HOTAIR overexpression, even in the absence of estrogen. When upregulated, HOTAIR interacts with the Polycomb group protein, EZH2, a component of PRC2 (Figure 2). The binding affinity of PRC2 with HOTAIR is enhanced by phosphorylation of EZH2 at Thr350 (in humans) in the G2/M phase of the cell cycle by cyclin-dependent kinase 1 
(CDK1) [65]. It is thought that EZH2 allows transcription of certain genes that are targets of estrogen, which prevents direct binding of estrogen to the regulatory elements of HOTAIR (Figure 2). Consistent with the roles of HOTAIR described above, depletion of HOTAIR was found to inhibit cell growth and colony-forming potential in tamoxifen-resistant breast cancer cells following exposure to tamoxifen [12]. Thus, these results suggest that HOTAIR is involved in conferring tamoxifen resistance to breast cancer cells by promoting the transcriptional activation of the ER, in a ligand-independent manner, providing a potential therapeutic target.

\section{Colon cancer associated transcript 2 (CCAT2)}

CCAT2 is an intergenic lncRNA mapping to chromosome $8 \mathrm{q} 24.21$, and has been implicated in a variety of cancers. This lncRNA has been reported to be up-regulated in cervical squamous cell carcinoma [66], hepatocellular carcinoma [67], gastric [68], prostate [69], ovarian [70] and gallbladder cancer [71]. Moreover, it has been found to promote tumorigenesis, invasion, metastasis, and chromosomal instability in colorectal cancer [72]. CCAT2 is also thought to be involved in the development of tamoxifen resistance in breast cancer [16] (Figure 1). Similarly, its expression was identified to be up-regulated ( $\sim 6.5$-fold) in tamoxifen-resistant versus tamoxifen-sensitive MCF-7 and T47D breast cancer cell lines; and as expected, knockdown of CCAT2 facilitated apoptosis and necrosis in tamoxifen-resistant cells [16]. It has been reported that the ERK/MAPK signaling pathway plays an important role in tamoxifen resistance in ER-positive breast cancer cells [13] (Figure 2). In the presence of a specific inhibitor of the ERK/MAPK pathway (U0126), the expression of CCAT2 decreased significantly in the tamoxifen-resistant breast cancer cells compared to normal cells, which suggest that the ERK/MAPK pathway regulates the expression of CCAT2 (Figure 2). Thus, these findings suggest that CCAT2 is involved in tamoxifen resistance in breast cancer cells and may provide a novel therapeutic molecule in the treatment of breast cancer and/or tamoxifin-resistant breast cancer patients. However, further study is warranted in breast cancer patients to consider CCAT2 as a useful biomarker.

\section{Breast cancer anti-estrogen resistance 4 (BCAR4)}

$B C A R 4$ is a relatively newly discovered lncRNA located on chromosome 16p13.13. As the name suggests, it was first identified in breast cancer [73], where its role was analyzed in association with tumorigenesis and chemoresistance to tamoxifen [18] (Figure 1). Recently, it was reported that $B C A R 4$ expression negatively correlates with breast cancer disease progression. To investigate the role of $B C A R 4$ in tamoxifen resistance in breast cancer, Godinho et al. (2010) analyzed the expression patterns of BCAR4 in 280 ER $\alpha$-positive breast cancer patients with advanced disease, who were administered tamoxifen monotherapy as a first line treatment [18]. The authors found that out of 280 breast cancer patients, 81 patients (29\%) showed high expression levels of the BCAR4 gene. However, no correlation between $B C A R 4$ gene levels and age, menopausal status, tumor size, modal status, or adjuvant systemic treatment of the patients was observed [67]. Further, it was found that patients with high levels of $B C A R 4$ were at increased risk of early recurrence of diseases and suffered low survival rates compared to patients having low levels of $B C A R 4$, reflecting the role of $B C A R 4$ in tumor aggressiveness. Previously, this same group reported that over-expression of $B C A R 4$ gives rise to aggressive phenotypes and anchorage-independent growth in breast cancer cell lines [73]. Mechanistically, $B C A R 4$ can increase the phosphorylation of $\mathrm{v}$-erb-b2 erythroblastic leukaemia viral oncogene homolog (ERBB)2, and ERBB3, resulting in the activation of essential downstream mediators of ERBB2/ERBB3 signaling, such as AKT and extracellular signal-regulated kinase 1/2 (ERK 1/2) [18] (Figure 2). Gene amplification and over-expression of human erythroblastosis oncogene $B$ (ERBB) up-regulates the HER2 receptor on the surface of breast cancer cells, which further induces the activation of the ER co-activator, amplified in breast cancer 1 (AIB-1)/steroid receptor coactivator-3 (SRC3 ), which can reduce the efficacy of tamoxifen therapy [74].

The suppression of ERBB2 by siRNA in tamoxifenresistant breast cancer cells resulted in a decrease in the proliferative ability of the cells, which reconfirms the involvement of the ERBB2/ERBB3 pathways in the development of chemoresistance to breast cancer cells. Previously, it was shown that the paired box 2 gene product (PAX2), a transcription factor that physically associates with an ER binding site [75] within the intron of the $E R B B 2$ gene and inhibits the transcription of ERBB2, enhanced the sensitivity of breast cancer cells to tamoxifen treatment [18]. Breast cancer cells are also characterized by increased levels of the ER co-activator amplified in breast cancer-1 (AIB-1) oncogene, which was found to be essential for ERBB2-driven oncogenesis in mice [76, 77]. PAX2 and AIB-1 compete for the ER binding site on ERBB2 in order to regulate its transcription. The upregulation of BCAR4 promotes AIB-1 activation, which competitively binds and inhibits the binding of PAX2 to ERBB2 sites, and thus promotes cell proliferation, tumorigenesis, and tamoxifen resistance (Figure 2) [74]. Taken together, these data suggest that BCAR4 plays an important role in breast tumor aggression and tamoxifen resistance, driven by the ERBB2/ERBB3 signalling pathways (Figure 2). 


\section{Urothelial carcinoma associated-1 (UCA1)}

LncRNA UCA1 is an intergenic long non-protein coding RNA, initially identified in bladder cancer [78]. It contains three exons, and encodes for two isoforms of $1.4 \mathrm{~kb}$ and $2.2 \mathrm{~kb}$ located on chromosome $19 \mathrm{q} 13.12$ in humans [79]. Several studies have identified UCA1 as an oncogenic factor in several different cancers, including breast cancer [80]. In breast cancer the $1.4 \mathrm{~kb}$ isoform of $U C A 1$ is up-regulated (20-fold) and exerts its oncogenic effect, in part by the formation of a UCA1hnRNP I (heterogeneous nuclear ribonucleoprotein I) complex, which results in suppression of $\mathrm{p} 27$ expression and promotes cancer cell proliferation [79]. UCA1 plays an important role in establishing chemoresistance in lung (gefitinib) [81], gastric (adriamycin) [82], breast (tamoxifen) [19], esophagus (cisplatin) [60], and ovarian (cisplatin) [83] cancers (Figure 1). Based on several studies, it is thought that UCA1 either manipulates the mTOR signaling pathway and/or exploits an miR18 a-HIF $1 \alpha$ feedback loop as well as the Wnt/ $\beta$-catenin signaling pathway to confer tamoxifen resistance in breast cancer $[19,79]$.

$\mathrm{Wu}$ et al. found substantially higher expression levels ( 20 fold) of UCA1 in the tamoxifen-resistant LLC2 and LLC9 breast cancer cells compared to MCF7 cells [19]. Further, depletion of UCA1 was shown to improve the sensitivity of breast cancer cells to tamoxifen [19], consistent with its role in tamoxifen resistance. Mechanistically, UCA1 is thought to promote tamoxifen resistance in breast cancer cells by activating the AKT/ mTOR signaling pathway, where several additional miRNAs are thought to be involved in the chemoresistance phenomenon [84]. Inhibition of some of these miRNAs (e.g. miR-21) promotes autophagic cell death and apoptosis by targeting PTEN via inhibition of the PI3KAKT-mTOR axis, thereby enhancing tamoxifen sensitivity in breast cancer cells [84]. Another microRNA, miR-451a, also contribute to tamoxifen sensitivity by de-regulating the activation of p-AKT and mTOR [85] (Figure 2).

Tamoxifen can up-regulate hypoxia inducible factor alpha (HIF1 $\alpha$ ), which binds to the hypoxia response elements in the UCA1 promoter to enhance its expression [86]. It has been reported that miR-18a, a tumor suppressor, acts as an inhibitor of HIF $1 \alpha$ by directly targeting its 3 'UTR. miR-18a can disrupt the cell cycle and DNA damage responses by regulating multiple cell-cycle associated proteins such as the ATM kinase [87]. It also inhibits $\mathrm{Cdc} 42$, a modulator of cellular proliferation, survival and metastasis in various cancers [88]. Over-expression of UCA1 acts as a molecular sponge and down-regulates miR-18a by associating with the Ago2-containing RNA-induced silencing complex (RISC) [21], supporting the idea that ER-positive breast cancer cells can acquire tamoxifen resistance via a UCA1-miR-18a-HIF $\alpha$ feedback loop (Figure 2) [20].
However, the proposed mechanism is still not clear. Liu et al. [21] demonstrated an interaction between UCA1 and the Wnt/ $\beta$-catenin signaling pathway in the context of tamoxifen resistance (Figure 2). When breast cancer cells are exposed to tamoxifen, the expression of HIF $1-\alpha$ increases, which stimulates over-expression of UCA1, and thereby enhances $\beta$-catenin translocation into the nucleus, promoting the extracellular redistribution of the ER [21]. $\beta$-catenin, an intracellular transducer of the wnt/ $\beta$-catenin signaling pathway, remains highly unstable and inactivated in the cytoplasm where it is subjected to phosphorylation/ubiquitination-associated proteasomal degradation [89]. Wnt/ $\beta$-catenin signaling inhibits the degradation of $\beta$-catenin and allows its accumulation in the nucleus, where it binds with the $\mathrm{T}$ cell factor/lymphoid enhancer factor (TCF/LEF) family of transcription factors and positively regulates wnt-associated genes (Figure 2) [89]. Therefore, UCAI-associated ER and Wnt/ $\beta$-catenin signaling contribute to breast cancer progression via tamoxifen resistance (Figure 2). Further studies revealed that the $\mathrm{Wnt} / \beta$-catenin pathway plays an essential role in maintaining the stem-cell like characteristics of breast cancer cells contributing to metastasis and reducing the efficacy of tamoxifen therapy [21].

Together, these findings reveal that lncRNA UCA1 induces chemoresistance to tamoxifen through different molecular pathways, and regulates several other miRNAs involved in breast cancer (Figure 2). Therefore, UCA1 may serve as a therapeutic target for developing a potential treatment against breast cancer, particularly in tamoxifenresistant patients.

\section{LncRNA-regulator of reprogramming (LncRNA-ROR)}

LncRNA-ROR is a long intergenic non-coding RNA, with a length of $2.6 \mathrm{~kb}$, comprised of four exons located on chromosome 18q21.31 [90,91]. In humans, the ROR gene is regulated by certain pluripotency-inducing transcription factors such as Sox2, Nanog and Oct4, resulting in an increased expression in embryonic and induced pluripotent stem cells [91]. LncRNA-ROR plays an important role in regulating breast carcinoma by inhibiting the activation of different cellular pathways such as the stress-induced p53 pathway [91]. It has also been reported to be up-regulated by up to 5 -fold in various cancers such as gallbladder cancer [92], gastric cancer [93], and nasopharyngeal carcinoma [90]. LncRNA-ROR promotes chemoresistance in head and neck [90] and breast cancers [22] against a variety of chemotherapeutic agents, including cisplatin and tamoxifen, respectively (Figure 1).

Recently, Zhang et al. (2017) analyzed the expression pattern of IncRNA-ROR in breast cancer cell lines using qRT-PCR, and found it to be significantly upregulated ( 7-fold) compared to breast epithelial MCF10A cell lines [22]. To determine the effects of IncRNA-ROR 
on breast cancer cells in relation to tamoxifen resistance, the proliferation rate of tamoxifen-resistant MCF7/TR5 breast cancer was compared with $\mathrm{MCF}-7$ cells. It was found that the MCF/TR5 cells showed significantly higher proliferation rates compared to the MCF-7 cells following treatment with tamoxifen. When siRNA was used to deplete ROR in naturally tamoxifen-resistance (MDAMB-231) and tamoxifen-induced breast cancer cells (MCF7/TR5), this resulted in lower rates of proliferation following treatment with tamoxifen, again implicating $R O R$ in the resistance phenotype. It was also demonstrated that cells having relatively low $R O R$ expression showed more sensitivity to tamoxifen compared to cells having higher $R O R$ expression. Moreover, western blot analysis revealed the contribution of $\ln c R N A-R O R$ in breast cancer cell invasion and the EMT process, as cell lines transfected with si-lncRNA-ROR showed an increased expression of E-cadherin (an epithelial marker) and decreased expression of Vimentin (a mesenchymal marker) [22] (Figure 2), which influenced the tamoxifen resistance ability of breast cancer cells.

At the molecular level, it was found that $\operatorname{lnc} R N A$ $R O R$ regulates the expression of ZEB1 and ZEB2 transcription factors, and as expected, the expression of ZEB1 and ZEB2 were significantly downregulated in ROR-siRNA treated MDA-MB-231 and MCF/TR5 cells [22]. As mentioned earlier, ZEB1 and ZEB2 are well known oncogenic transcription factors that play crucial roles in regulating the EMT process [94]. Principally, lncRNA-ROR interacts with miR-205-5p ribonucelopotein complex and functions as a molecular sponge for miR205-5p. For example, it was reported that miR-205-5p acts as a negative regulator of the EMT process by silencing the expression of the $Z E B 1 / 2$ genes by binding to their 3'UTRs in gastric cancer [95]. To better understand its role in the context of breast cancer resistance, the authors found that upregulation of $\ln c R N A-R O R$ in tamoxifen resistant MCF7/TR5 and MDA-MB-231 breast cancer cells inhibited the expression of miR-205-5p, and increased ZEB1/2 gene expression, thereby enhancing the EMT process (Figure 2).

Collectively, these results suggest that LncRNA-ROR acts as an oncogenic molecule in breast cancer, in part by inhibiting miR-205-5p and promoting the EMT process by enhancing the expression of ZEB1 and ZEB2 transcription factors, contributing to breast cancer cell invasion as well as tamoxifen resistance (Figure 2). Thus, LncRNA-ROR may potentially serve as a biomarker for assessing the sensitivity of breast cancer cells to tamoxifen, though further research is required to explore it's role in vivo.

\section{H19}

H19, an imprinted maternally expressed transcript $(\sim 2.3$ $\mathrm{kb}$ ), is located on chromosome $11 \mathrm{p} 15.5$. It is classified as a nonprotein coding RNA that plays an essential role in mammalian development [96]. Several investigations have confirmed that $H 19$ is over-expressed in bladder [97], glioma [98], thyroid [99], gastric [100] and breast cancers [101] through various mechanisms, including chromosomal abnormalities, transcription factor binding, and epigenetic alterations. High levels of $H 19$ often correlate with poor prognosis for cancer patients, and with the development of chemoresistance in various cancers, including ovarian (cisplatin) [102], colorectal (methotrexate) [103], liver (doxorubicin) [104] lung (cisplatin) [105], and breast (paclitaxel) [17] (Figure 1).

The expression of $H 19$ was found to be highly upregulated in paclitaxel induced ER $\alpha$-positive resistant breast cancer cell lines MCF-7R and ZR-75-1 (by 9fold and 4-fold, respectively) compared to their parental lines MCF-7S and ZR-75-1S [17]. While no up-regulation was observed in the ER $\alpha$-negative breast cancer cell line MDA-MB-231 even in the presence of paclitaxel [17]. Similarly Lu et al. [106] demonstrated a higher expression (3-fold) of $H 19$ in ER $\alpha$-positive breast cancer patients $(\mathrm{n}=76)$ than in ER $\alpha$-negative breast cancer patients $(\mathrm{n}=53)$, which suggests a possible involvement of ER $\alpha$ in the up-regulation of $H 19$ in chemoresistant cancer cells. Since ER $\alpha$ is considered a powerful chemoresistance factor, the authors examined whether depletion of $H 19$ could attenuate ER $\alpha$-induced drug resistance. They found that suppression of $H 19$ expression sensitized MCF$7 \mathrm{~S}$ cells to paclitaxel, suggesting that ER $\alpha$ promoted $H 19$ expression in breast cancer cells and that H19 is an important mediator of ER $\alpha$-induced drug resistance [17]. The contribution of $H 19$ was further verified in MCF-7R and ZR-75-1R cells transfected with H19-targeting siRNA and treated with different concentration of paclitaxel for 48 h. By MTT assays, it was observed that both MCF-7R and ZR-75-1R cells showed decreased viability following treatment with paclitaxel, suggesting that $H 19$ contributes to drug resistance in breast cancer. Previous studies reported that $\mathrm{H} 19$ induces $\mathrm{P}$-glycoprotein expression under hypoxic conditions, which promotes the cellular efflux of specific drugs, including paclitaxel and epirubicin [101]. It was observed that knockdown of H19 significantly reversed resistance even to drugs that were not substrates of P-glycoprotein, indicating H19 induced breast cancer chemoresistance through multiple mechanisms. It was also found that $H 19$ attenuated apoptosis by inhibiting the transcription of the pro-apoptotic proteins BCL-2 interacting killer (BIK) and the BCL-2 homology domain 3 (BH3) protein, NOXA [107]. The protein levels of BIK and NOXA increased in H19-depleted cells, which increased the apoptotic ratio of the cells [17]. Furthermore, the over-expression of BIK or NOXA (by 2.5-fold) in MCF-7R cells decreased the survival of paclitaxelresistant cells via increased apoptosis [17]. The authors also demonstrated that $H 19$, by recruiting $\mathrm{EZH} 2$, an essential component of PRC2, catalyses the trimethylation of $\mathrm{H} 3 \mathrm{~K} 27$ in the promoter region of BIK, suppressing its 
transcription (Figure 2). However, how H19 inhibits the transcription of NOXA is not yet clear.

Taken together, these results suggest that the ER $\alpha$ H19-BIK axis plays an important role in contributing to drug resistance in breast cancer chemotherapy. Thus, modulation of the components of this signalling axis may be used to overcome paclitaxel resistance in breast cancer patients.

\section{LncRNA-adriamycin resistance associated (LncRNA-ARA)}

LncRNA-ARA is a 4,957 nt unspliced, polyadenylated transcript transcribed from the intron of the $\mathrm{p} 21$-activated kinase 3 (PAK3) gene at chromosome Xq23 [23]. Jiang et al. through genome-wide lncRNA microarray analysis, reported the differential expression of $\ln c R N A-A R A$ in adriamycin resistant MCF-7/ADR breast cancer cells compared to parental MCF-7 cells [23]. The authors have shown that depletion of IncRNA-ARA by ARAsiRNA sensitized MCF-7/ADR cells to adriamycin, which suggests that lncRNA-ARA may be a candidate molecule in the development of resistance against adriamycin in breast cancer cells. The authors also demonstrated that the endogenous expression of $\operatorname{lncRNA-ARA}$ was upregulated by $\sim 13$-fold at 48 hours following treatment with adriamycin in sensitive MCF-7 cells, whereas no significant change was observed at same time point and drug concentration in MCF-7/ADR cells, indicating that drug treatment might initially induce ARA expression during the development of drug resistance. It was further observed that siRNA-mediated silencing of $\ln c R N A-A R A$ inhibited cellular proliferation, induced a G2/M arrest, and enhanced cell death via apoptosis, necrosis, and migration defects in adriamycin-resistant cells. Also, ARA depletion resulted in the upregulation of the pro-apoptotic Bcl-2 Associated $\mathrm{X}(\mathrm{BAX})$ protein and the downregulation of the anti-apoptotic B-cell lymphoma extra-large (Bcl-xL) protein, hence playing a role in apoptosis and cell death. By using bioinformatics tools such as gene ontology (GO) and pathway mapping tools such as Kyoto encyclopaedia of genes and genomes (KEGG), lncRNA-ARA was found to regulate multiple oncogenic signalling pathways such as purine metabolism, pyrimidine metabolism, focal adhesion, cell cycle, PPAR signaling and MAPK signaling in cells, all of which have been reported to contribute to acquisition of adriamycin resistance in breast cancer [4, 108-110].

Taken together, the above findings suggest a novel role of $\ln c R N A-A R A$ in contributing to adriamycin resistance in breast cancer cells, although further study is required, especially in breast cancer patients.

\section{CONCLUSIONS}

It is very disheartening that even with the availability of many chemotherapeutic regimens for the treatment of breast cancer (Figure 1), the main causes of breast cancer-related deaths include recurrence and metastases [2]. Accurately predicting those patients at high risk for recurrence may afford improved monitoring and treatment for breast cancer patients. The dysregulated expression and stabilization of lncRNAs (Table 1) has recently been established as a critical factor for modulating epigenetic changes in immune signaling pathways, DNA repair pathways, cell death pathways and energy metabolism, particularly in rendering tumor cells refractory to chemotherapeutic interventions. Here, we discussed how lncRNA pools can influence the expression of various oncogenes and cancer signaling pathways, and can also affect the angiogenesis, metastasis, immune evasion, and EMT processes involved in cancer etiology and progression (Figure 2).

In conclusion, we are hopeful that this review will contribute to the better understanding of the development of chemoresistance in breast cancer cells and the roles of long non-coding RNAs in these processes. Thus, with further work in this field, lncRNAs may be developed as a biomarkers for the detection and/or prevention of breast cancer. Additionally, lncRNA-based approaches may provide an additional treatment modality in personalized medicine alone or in combination with existing tumor directed interventions to improve patient outcome. Thus, lncRNA molecules may represent a "next generation" therapy option for breast cancer patients.

\section{ACKNOWLEDGMENTS AND FUNDING}

This work was supported by the Department of Science and Technology of India through the Ramanujan fellowship (SR/S2/RJN-95/2011) to AJ and HP (SR/ $\mathrm{S} 2 / \mathrm{RJN}-03 / 2012$ ) and an NIH/NCI grant to $\mathrm{KMV}$ (CA093279). AJ is also thankful to Department of Biotechnology, India for providing grant (6242-P30/ RGCB/PMD/DBT/AKJN/2015) and Central University Punjab, Bathinda for the RSM grant (GP-25). MJ is thankful to the DST-SERB for fellowship under the Fast Track Young Scientist Scheme (SB/YS/LS-320/2013).

\section{CONFLICTS OF INTEREST}

None.

\section{REFERENCES}

1. Lukong KE. Understanding breast cancer - The long and winding road. BBA Clin. 2017; 7:64-77. https://doi. org/10.1016/j.bbacli.2017.01.001.

2. Siegel RL, Miller KD, Jemal A. Cancer statistics, 2016. CA Cancer J Clin. 2016; 66:7-30. https://doi.org/10.3322/ caac. 21332.

3. Chen L, Linden HM, Anderson BO, Li CI. Trends in 5-year survival rates among breast cancer patients by hormone 
receptor status and stage. Breast Cancer Res Treat. 2014; 147:609-16. https://doi.org/10.1007/s10549-014-3112-6.

4. Elliott $T$, Sethi T. Integrins and extracellular matrix: a novel mechanism of multidrug resistance. Expert Rev Anticancer Ther. 2002; 2:449-59. https://doi. org/10.1586/14737140.2.4.449.

5. Khandelwal A, Bacolla A, Vasquez KM, Jain A. Long noncoding RNA: A new paradigm for lung cancer. Mol Carcinog. 2015; 54:1235-51. https://doi.org/10.1002/mc.22362.

6. Kapranov P, Cheng J, Dike S, Nix DA, Duttagupta R, Willingham AT, Stadler PF, Hertel J, Hackermuller J, Hofacker IL, Bell I, Cheung E, Drenkow J, et al. RNA maps reveal new RNA classes and a possible function for pervasive transcription. Science. 2007; 316:1484-8. https:// doi.org/10.1126/science.1138341.

7. Spizzo R, Almeida MI, Colombatti A, Calin GA. Long noncoding RNAs and cancer: a new frontier of translational research? Oncogene. 2012; 31:4577-87. https://doi. org/10.1038/onc.2011.621.

8. Rinn JL, Chang HY. Genome regulation by long noncoding RNAs. Annu Rev Biochem. 2012; 81:145-66. https://doi. org/10.1146/annurev-biochem-051410-092902.

9. Fatica A, Bozzoni I. Long non-coding RNAs: new players in cell differentiation and development. Nat Rev Genet. 2014; 15:7-21. https://doi.org/10.1038/nrg3606.

10. Majidinia M, Yousefi B. Long non-coding RNAs in cancer drug resistance development. DNA Repair (Amst). 2016; 45:25-33. https://doi.org/10.1016/j.dnarep.2016.06.003.

11. Khandelwal A, Malhotra A, Jain M, Vasquez KM, Jain A. The emerging role of long non-coding RNA in gallbladder cancer pathogenesis. Biochimie. 2017; 132:152-60. https:// doi.org/10.1016/j.biochi.2016.11.007.

12. Shi SJ, Wang LJ, Yu B, Li YH, Jin Y, Bai XZ. LncRNAATB promotes trastuzumab resistance and invasionmetastasis cascade in breast cancer. Oncotarget. 2015; 6:11652-63. https://doi.org/10.18632/oncotarget.3457.

13. Li W, Zhai L, Wang H, Liu C, Zhang J, Chen W, Wei Q. Downregulation of LncRNA GAS5 causes trastuzumab resistance in breast cancer. Oncotarget. 2016; 7:27778-86. https://doi.org/10.18632/oncotarget.8413.

14. Chu EC, Tarnawski AS. PTEN regulatory functions in tumor suppression and cell biology. Med Sci Monit. 2004; 10:RA235-41.

15. Xue X, Yang YA, Zhang A, Fong KW, Kim J, Song B, Li S, Zhao JC, Yu J. LncRNA HOTAIR enhances ER signaling and confers tamoxifen resistance in breast cancer. Oncogene. 2016; 35:2746-55. https://doi.org/10.1038/onc.2015.340.

16. Cai Y, He J, Zhang D. [Suppression of long non-coding RNA CCAT2 improves tamoxifen-resistant breast cancer cells' response to tamoxifen]. [Article in Russian]. Mol Biol (Mosk). 2016; 50:821-7. https://doi.org/10.7868/ S0026898416030046.

17. Si X, Zang R, Zhang E, Liu Y, Shi X, Zhang E, Shao L, Li A, Yang N, Han X, Pan B, Zhang Z, Sun L, Sun Y. LncRNA
H19 confers chemoresistance in ERalpha-positive breast cancer through epigenetic silencing of the pro-apoptotic gene BIK. Oncotarget. 2016; 7:81452-62. https://doi. org/10.18632/oncotarget.13263.

18. Godinho MF, Sieuwerts AM, Look MP, Meijer D, Foekens JA, Dorssers LC, van Agthoven T. Relevance of BCAR4 in tamoxifen resistance and tumour aggressiveness of human breast cancer. Br J Cancer. 2010; 103:1284-91. https://doi. org/10.1038/sj.bjc.6605884.

19. Wu C, Luo J. Long Non-Coding RNA (lncRNA) Urothelial Carcinoma-Associated 1 (UCA1) Enhances Tamoxifen Resistance in Breast Cancer Cells via Inhibiting mTOR Signaling Pathway. Med Sci Monit. 2016; 22:3860-7.

20. Li X, Wu Y, Liu A, Tang X. Long non-coding RNA UCA1 enhances tamoxifen resistance in breast cancer cells through a miR-18a-HIF1alpha feedback regulatory loop. Tumour Biol. 2016; 37:14733-43. https://doi.org/10.1007/s13277016-5348-8.

21. Liu H, Wang G, Yang L, Qu J, Yang Z, Zhou X. Knockdown of Long Non-Coding RNA UCA1 Increases the Tamoxifen Sensitivity of Breast Cancer Cells through Inhibition of Wnt/beta-Catenin Pathway. PLoS One. 2016; 11:e0168406. https://doi.org/10.1371/journal.pone.0168406.

22. Zhang HY, Liang F, Zhang JW, Wang F, Wang L, Kang XG. Effects of long noncoding RNA-ROR on tamoxifen resistance of breast cancer cells by regulating microRNA-205. Cancer Chemother Pharmacol. 2017; 79:327-37. https://doi.org/10.1007/s00280-016-3208-2.

23. Jiang M, Huang O, Xie Z, Wu S, Zhang X, Shen A, Liu H, Chen X, Wu J, Lou Y, Mao Y, Sun K, Hu S, et al. A novel long non-coding RNA-ARA: adriamycin resistanceassociated. Biochem Pharmacol. 2014; 87:254-83. https:// doi.org/10.1016/j.bcp.2013.10.020.

24. Zhu HY, Bai WD, Li C, Zheng Z, Guan H, Liu JQ, Yang XK, Han SC, Gao JX, Wang HT, Hu DH. Knockdown of lncRNA-ATB suppresses autocrine secretion of TGF-beta2 by targeting ZNF217 via miR-200c in keloid fibroblasts. Sci Rep. 2016; 6:24728. https://doi.org/10.1038/srep24728.

25. Xiong J, Liu Y, Jiang L, Zeng Y, Tang W. High expression of long non-coding RNA lncRNA-ATB is correlated with metastases and promotes cell migration and invasion in renal cell carcinoma. Jpn J Clin Oncol. 2016; 46:378-84. https://doi.org/10.1093/jjco/hyv214.

26. Ma J, Cui X, Rong Y, Zhou Y, Guo Y, Zhou M, Xiao L, Chen W. Plasma LncRNA-ATB, a Potential Biomarker for Diagnosis of Patients with Coal Workers' Pneumoconiosis: A Case-Control Study. Int J Mol Sci. 2016; 17. https://doi. org/10.3390/ijms17081367.

27. Iguchi T, Uchi R, Nambara S, Saito T, Komatsu H, Hirata H, Ueda M, Sakimura S, Takano Y, Kurashige J, Shinden Y, Eguchi H, Sugimachi K, et al. A long noncoding RNA, lncRNA-ATB, is involved in the progression and prognosis of colorectal cancer. Anticancer Res. 2015; 35:1385-8.

28. Xu S, Yi XM, Tang CP, Ge JP, Zhang ZY, Zhou WQ. Long non-coding RNA ATB promotes growth and epithelial- 
mesenchymal transition and predicts poor prognosis in human prostate carcinoma. Oncol Rep. 2016; 36:10-22. https://doi.org/10.3892/or.2016.4791.

29. Saito T, Kurashige J, Nambara S, Komatsu H, Hirata H, Ueda M, Sakimura S, Uchi R, Takano Y, Shinden Y, Iguchi T, Eguchi H, Ehata S, et al. A Long Non-coding RNA Activated by Transforming Growth Factor-beta is an Independent Prognostic Marker of Gastric Cancer. Ann Surg Oncol. 2015; 22:S915-22. https://doi.org/10.1245/ s10434-015-4554-8.

30. Wang SE. The Functional Crosstalk between HER2 Tyrosine Kinase and TGF-beta Signaling in Breast Cancer Malignancy. J Signal Transduct. 2011; 2011:804236. https:// doi.org/10.1155/2011/804236.

31. Burk U, Schubert J, Wellner U, Schmalhofer O, Vincan E, Spaderna S, Brabletz T. A reciprocal repression between ZEB1 and members of the miR-200 family promotes EMT and invasion in cancer cells. EMBO Rep. 2008; 9:582-9. https://doi.org/10.1038/embor.2008.74.

32. Vendrell JA, Thollet A, Nguyen NT, Ghayad SE, Vinot S, Bieche I, Grisard E, Josserand V, Coll JL, Roux P, Corbo L, Treilleux I, Rimokh R, et al. ZNF217 is a marker of poor prognosis in breast cancer that drives epithelial-mesenchymal transition and invasion. Cancer Res. 2012; 72:3593-606. https://doi.org/10.1158/0008-5472.CAN-11-3095.

33. Smith CM, Steitz JA. Classification of gas5 as a multismall-nucleolar-RNA (snoRNA) host gene and a member of the 5'-terminal oligopyrimidine gene family reveals common features of snoRNA host genes. Mol Cell Biol. 1998; 18:6897-909.

34. Shi X, Sun M, Liu H, Yao Y, Kong R, Chen F, Song Y. A critical role for the long non-coding RNA GAS5 in proliferation and apoptosis in non-small-cell lung cancer. Mol Carcinog. 2015; 54:E1-E12. https://doi.org/10.1002/ mc. 22120 .

35. Zhang N, Wang AY, Wang XK, Sun XM, Xue HZ. GAS5 is downregulated in gastric cancer cells by promoter hypermethylation and regulates adriamycin sensitivity. Eur Rev Med Pharmacol Sci. 2016; 20:3199-205.

36. Zhao X, Wang P, Liu J, Zheng J, Liu Y, Chen J, Xue Y. Gas5 Exerts Tumor-suppressive Functions in Human Glioma Cells by Targeting miR-222. Mol Ther. 2015; 23:1899-911. https://doi.org/10.1038/mt.2015.170.

37. Liu Y, Zhao J, Zhang W, Gan J, Hu C, Huang G, Zhang Y. lncRNA GAS5 enhances G1 cell cycle arrest via binding to $\mathrm{YBX} 1$ to regulate $\mathrm{p} 21$ expression in stomach cancer. Sci Rep. 2015; 5:10159. https://doi.org/10.1038/srep10159.

38. Dong S, Qu X, Li W, Zhong X, Li P, Yang S, Chen X, Shao M, Zhang L. The long non-coding RNA, GAS5, enhances gefitinib-induced cell death in innate EGFR tyrosine kinase inhibitor-resistant lung adenocarcinoma cells with wide-type EGFR via downregulation of the IGF-1R expression. J Hematol Oncol. 2015; 8:43. https://doi.org/10.1186/s13045-015-0140-6.

39. Cao S, Liu W, Li F, Zhao W, Qin C. Decreased expression of lncRNA GAS5 predicts a poor prognosis in cervical cancer. Int J Clin Exp Pathol. 2014; 7:6776-83.
40. Tu ZQ, Li RJ, Mei JZ, Li XH. Down-regulation of long non-coding RNA GAS5 is associated with the prognosis of hepatocellular carcinoma. Int J Clin Exp Pathol. 2014; 7:4303-9.

41. Liu Z, Wang W, Jiang J, Bao E, Xu D, Zeng Y, Tao L, Qiu J. Downregulation of GAS5 promotes bladder cancer cell proliferation, partly by regulating CDK6. PLoS One. 2013; 8:e73991. https://doi.org/10.1371/journal.pone.0073991.

42. Lu X, Fang Y, Wang Z, Xie J, Zhan Q, Deng X, Chen H, Jin J, Peng C, Li H, Shen B. Downregulation of gas 5 increases pancreatic cancer cell proliferation by regulating CDK6. Cell Tissue Res. 2013; 354:891-6. https://doi.org/10.1007/ s00441-013-1711-x.

43. Pickard MR, Mourtada-Maarabouni M, Williams GT. Long non-coding RNA GAS5 regulates apoptosis in prostate cancer cell lines. Biochim Biophys Acta. 2013; 1832:161323. https://doi.org/10.1016/j.bbadis.2013.05.005.

44. Zhang H, Guo Y, Song Y, Shang C. Long noncoding RNA GAS5 inhibits malignant proliferation and chemotherapy resistance to doxorubicin in bladder transitional cell carcinoma. Cancer Chemother Pharmacol. 2017; 79:49-55. https://doi.org/10.1007/s00280-016-3194-4.

45. Yacqub-Usman K, Pickard MR, Williams GT. Reciprocal regulation of GAS5 lncRNA levels and mTOR inhibitor action in prostate cancer cells. Prostate. 2015; 75:693-705. https://doi.org/10.1002/pros.22952.

46. Gupta RA, Shah N, Wang KC, Kim J, Horlings HM, Wong DJ, Tsai MC, Hung T, Argani P, Rinn JL, Wang Y, Brzoska P, Kong B, et al. Long non-coding RNA HOTAIR reprograms chromatin state to promote cancer metastasis. Nature. 2010; 464:1071-6. https://doi.org/10.1038/ nature 08975.

47. Wang Y, Wang H, Song T, Zou Y, Jiang J, Fang L, Li P. HOTAIR is a potential target for the treatment of cisplatinresistant ovarian cancer. Mol Med Rep. 2015; 12:2211-6. https://doi.org/10.3892/mmr.2015.3562.

48. Liu XH, Sun M, Nie FQ, Ge YB, Zhang EB, Yin DD, Kong R, Xia R, Lu KH, Li JH, De W, Wang KM, Wang ZX. Lnc RNA HOTAIR functions as a competing endogenous RNA to regulate HER2 expression by sponging miR-331$3 p$ in gastric cancer. Mol Cancer. 2014; 13:92. https://doi. org/10.1186/1476-4598-13-92.

49. Zhu Y, Yu RK, Ji AF, Yao XL, Fang JJ, Jin XD. [Effects of long non-coding RNA-HOTAIR on the cell cycle and invasiveness of prostate cancer]. [Article in Chinese]. Zhonghua Nan Ke Xue. 2015; 21:792-6.

50. Wu Y, Liu J, Zheng Y, You L, Kuang D, Liu T. Suppressed expression of long non-coding RNA HOTAIR inhibits proliferation and tumourigenicity of renal carcinoma cells. Tumour Biol. 2014; 35:11887-94. https://doi.org/10.1007/ s13277-014-2453-4.

51. Jing L, Yuan W, Ruofan D, Jinjin Y, Haifeng Q. HOTAIR enhanced aggressive biological behaviors and induced radio-resistance via inhibiting p21 in cervical cancer. 
Tumour Biol. 2015; 36:3611-9. https://doi.org/10.1007/ s13277-014-2998-2.

52. Wu H, Shang X, Shi Y, Yang Z, Zhao J, Yang M, Li Y, Xu S. Genetic variants of lncRNA HOTAIR and risk of epithelial ovarian cancer among Chinese women. Oncotarget. 2016; 7:41047-52. https://doi.org/10.18632/oncotarget.8535.

53. Martinez-Fernandez M, Feber A, Duenas M, Segovia C, Rubio C, Fernandez M, Villacampa F, Duarte J, Lopez-Calderon FF, Gomez-Rodriguez MJ, Castellano D, Rodriguez-Peralto JL, de la Rosa F, et al. Analysis of the Polycomb-related lncRNAs HOTAIR and ANRIL in bladder cancer. Clin Epigenetics. 2015; 7:109. https://doi. org/10.1186/s13148-015-0141-x.

54. Ono H, Motoi N, Nagano H, Miyauchi E, Ushijima M, Matsuura M, Okumura S, Nishio M, Hirose T, Inase N, Ishikawa Y. Long noncoding RNA HOTAIR is relevant to cellular proliferation, invasiveness, and clinical relapse in small-cell lung cancer. Cancer Med. 2014; 3:632-42. https://doi.org/10.1002/cam4.220.

55. Teschendorff AE, Lee SH, Jones A, Fiegl H, Kalwa M, Wagner W, Chindera K, Evans I, Dubeau L, Orjalo A, Horlings HM, Niederreiter L, Kaser A, et al. HOTAIR and its surrogate DNA methylation signature indicate carboplatin resistance in ovarian cancer. Genome Med. 2015; 7:108. https://doi.org/10.1186/s13073-015-0233-4.

56. Yan J, Dang Y, Liu S, Zhang Y, Zhang G. LncRNA HOTAIR promotes cisplatin resistance in gastric cancer by targeting miR-126 to activate the PI3K/AKT/MRP1 genes. Tumour Biol. 2016; 37:16345-1635. https://doi.org/10.1007/ s13277-016-5448-5.

57. Liu MY, Li XQ, Gao TH, Cui Y, Ma N, Zhou Y, Zhang GJ. Elevated HOTAIR expression associated with cisplatin resistance in non-small cell lung cancer patients. J Thorac Dis. 2016; 8:3314-22. https://doi.org/10.21037/ jtd.2016.11.75.

58. Liu Z, Sun M, Lu K, Liu J, Zhang M, Wu W, De W, Wang Z, Wang R. The long noncoding RNA HOTAIR contributes to cisplatin resistance of human lung adenocarcinoma cells via downregualtion of $\mathrm{p} 21$ (WAF1/CIP1) expression. PLoS One. 2013; 8:e77293. https://doi.org/10.1371/journal. pone.0077293.

59. Wang H, Li Q, Tang S, Li M, Feng A, Qin L, Liu Z, Wang X. The role of long noncoding RNA HOTAIR in the acquired multidrug resistance to imatinib in chronic myeloid leukemia cells. Hematology. 2017; 22:208-16. https://doi.org/10.1080/10245332.2016.1258152.

60. Zhou XL, Wang WW, Zhu WG, Yu CH, Tao GZ, Wu QQ, Song YQ, Pan P, Tong YS. High expression of long non-coding RNA AFAP1-AS1 predicts chemoradioresistance and poor prognosis in patients with esophageal squamous cell carcinoma treated with definitive chemoradiotherapy. Mol Carcinog. 2016; 55:2095-105. https://doi.org/10.1002/mc.22454.

61. Chang M. Tamoxifen resistance in breast cancer. Biomol Ther (Seoul). 2012; 20:256-67. https://doi.org/10.4062/ biomolther.2012.20.3.256.
62. Jensen EV, Jordan VC. The estrogen receptor: a model for molecular medicine. Clin Cancer Res. 2003; 9:1980-9.

63. Doisneau-Sixou SF, Sergio CM, Carroll JS, Hui R, Musgrove EA, Sutherland RL. Estrogen and antiestrogen regulation of cell cycle progression in breast cancer cells. Endocr Relat Cancer. 2003; 10:179-86.

64. Singh B, Bhat NK, Bhat HK. Partial inhibition of estrogeninduced mammary carcinogenesis in rats by tamoxifen: balance between oxidant stress and estrogen responsiveness. PLoS One. 2011; 6:e25125. https://doi.org/10.1371/journal. pone.0025125.

65. Kaneko S, Li G, Son J, Xu CF, Margueron R, Neubert TA, Reinberg D. Phosphorylation of the PRC2 component Ezh2 is cell cycle-regulated and up-regulates its binding to ncRNA. Genes Dev. 2010; 24:2615-20. https://doi. org/10.1101/gad.1983810.

66. Chen X, Liu L, Zhu W. Up-regulation of long non-coding RNA CCAT2 correlates with tumor metastasis and poor prognosis in cervical squamous cell cancer patients. Int $\mathrm{J}$ Clin Exp Pathol. 2015; 8:13261-6.

67. Zhou N, Si Z, Li T, Chen G, Zhang Z, Qi H. Long noncoding RNA CCAT2 functions as an oncogene in hepatocellular carcinoma, regulating cellular proliferation, migration and apoptosis. Oncol Lett. 2016; 12:132-8. https://doi.org/10.3892/ol.2016.4580.

68. Wang YJ, Liu JZ, Lv P, Dang Y, Gao JY, Wang Y. Long noncoding RNA CCAT2 promotes gastric cancer proliferation and invasion by regulating the E-cadherin and LATS2. Am J Cancer Res. 2016; 6:2651-60.

69. Zheng J, Zhao S, He X, Zheng Z, Bai W, Duan Y, Cheng S, Wang J, Liu X, Zhang G. The up-regulation of long noncoding RNA CCAT2 indicates a poor prognosis for prostate cancer and promotes metastasis by affecting epithelialmesenchymal transition. Biochem Biophys Res Commun. 2016; 480:508-14. https://doi.org/10.1016/j.bbrc.2016.08.120.

70. Huang S, Qing C, Huang Z, Zhu Y. The long non-coding RNA CCAT2 is up-regulated in ovarian cancer and associated with poor prognosis. Diagn Pathol. 2016; 11:49. https://doi.org/10.1186/s13000-016-0499-x.

71. Li J, Zhuang C, Liu Y, Chen M, Zhou Q, Chen Z, He A, Zhao G, Guo Y, Wu H, Cai Z, Huang W. shRNA targeting long non-coding RNA CCAT2 controlled by tetracyclineinducible system inhibits progression of bladder cancer cells. Oncotarget. 2016; 7:28989-97. https://doi. org/10.18632/oncotarget.8259.

72. Ling H, Spizzo R, Atlasi Y, Nicoloso M, Shimizu M, Redis RS, Nishida N, Gafa R, Song J, Guo Z, Ivan C, Barbarotto E, De Vries I, et al. CCAT2, a novel noncoding RNA mapping to $8 \mathrm{q} 24$, underlies metastatic progression and chromosomal instability in colon cancer. Genome Res. 2013; 23:1446-61. https://doi.org/10.1101/ gr.152942.112.

73. Meijer D, van Agthoven T, Bosma PT, Nooter K, Dorssers LC. Functional screen for genes responsible for tamoxifen resistance in human breast cancer cells. Mol Cancer Res. 2006; 4:379-86. https://doi.org/10.1158/1541-7786.MCR-05-0156. 
74. Osborne CK, Bardou V, Hopp TA, Chamness GC, Hilsenbeck SG, Fuqua SA, Wong J, Allred DC, Clark GM, Schiff R. Role of the estrogen receptor coactivator AIB1 (SRC-3) and HER-2/neu in tamoxifen resistance in breast cancer. J Natl Cancer Inst. 2003; 95:353-61.

75. Hurtado A, Holmes KA, Geistlinger TR, Hutcheson IR, Nicholson RI, Brown M, Jiang J, Howat WJ, Ali S, Carroll JS. Regulation of ERBB2 by oestrogen receptor-PAX2 determines response to tamoxifen. Nature. 2008; 456:6636. https://doi.org/10.1038/nature07483.

76. Torres-Arzayus MI, Font de Mora J, Yuan J, Vazquez F, Bronson R, Rue M, Sellers WR, Brown M. High tumor incidence and activation of the PI3K/AKT pathway in transgenic mice define AIB1 as an oncogene. Cancer Cell. 2004; 6:263-74. https://doi.org/10.1016/j.ccr.2004.06.027.

77. Fereshteh MP, Tilli MT, Kim SE, Xu J, O’Malley BW, Wellstein A, Furth PA, Riegel AT. The nuclear receptor coactivator amplified in breast cancer-1 is required for Neu (ErbB2/HER2) activation, signaling, and mammary tumorigenesis in mice. Cancer Res. 2008; 68:3697-706. https://doi.org/10.1158/0008-5472.CAN-07-6702.

78. Wang XS, Zhang Z, Wang HC, Cai JL, Xu QW, Li MQ, Chen YC, Qian XP, Lu TJ, Yu LZ, Zhang Y, Xin DQ, $\mathrm{Na} Y Q$, et al. Rapid identification of UCA1 as a very sensitive and specific unique marker for human bladder carcinoma. Clin Cancer Res. 2006; 12:4851-8. https://doi. org/10.1158/1078-0432.CCR-06-0134.

79. Huang J, Zhou N, Watabe K, Lu Z, Wu F, Xu M, Mo YY. Long non-coding RNA UCA1 promotes breast tumor growth by suppression of p27 (Kip1). Cell Death Dis. 2014; 5:e1008. https://doi.org/10.1038/cddis.2013.541.

80. Tuo YL, Li XM, Luo J. Long noncoding RNA UCA1 modulates breast cancer cell growth and apoptosis through decreasing tumor suppressive miR-143. Eur Rev Med Pharmacol Sci. 2015; 19:3403-11.

81. Cheng N, Cai W, Ren S, Li X, Wang Q, Pan H, Zhao M, Li J, Zhang Y, Zhao C, Chen X, Fei K, Zhou C, Hirsch FR. Long non-coding RNA UCA1 induces non-T790M acquired resistance to EGFR-TKIs by activating the AKT/mTOR pathway in EGFR-mutant non-small cell lung cancer. Oncotarget. 2015; 6:23582-93. https://doi.org/10.18632/ oncotarget.4361.

82. Shang C, Guo Y, Zhang J, Huang B. Silence of long noncoding RNA UCA1 inhibits malignant proliferation and chemotherapy resistance to adriamycin in gastric cancer. Cancer Chemother Pharmacol. 2016; 77:1061-7. https:// doi.org/10.1007/s00280-016-3029-3.

83. Wang F, Zhou J, Xie X, Hu J, Chen L, Hu Q, Guo H, Yu C. Involvement of SRPK1 in cisplatin resistance related to long non-coding RNA UCA1 in human ovarian cancer cells. Neoplasma. 2015; 62:432-8.

84. Yu X, Li R, Shi W, Jiang T, Wang Y, Li C, Qu X. Silencing of MicroRNA-21 confers the sensitivity to tamoxifen and fulvestrant by enhancing autophagic cell death through inhibition of the PI3K-AKT-mTOR pathway in breast cancer cells. Biomed Pharmacother. 2016; 77:37-44. https://doi.org/10.1016/j.biopha.2015.11.005.

85. Liu ZR, Song Y, Wan LH, Zhang YY, Zhou LM. Overexpression of miR-451a can enhance the sensitivity of breast cancer cells to tamoxifen by regulating 14-3-3zeta, estrogen receptor alpha, and autophagy. Life Sci. 2016; 149:104-13. https://doi.org/10.1016/j.lfs.2016.02.059.

86. Xue M, Li X, Li Z, Chen W. Urothelial carcinoma associated 1 is a hypoxia-inducible factor-1alpha-targeted long noncoding RNA that enhances hypoxic bladder cancer cell proliferation, migration, and invasion. Tumour Biol. 2014; 35:6901-12. https://doi.org/10.1007/s13277-014-1925-x.

87. Song L, Lin C, Wu Z, Gong H, Zeng Y, Wu J, Li M, Li J. miR-18a impairs DNA damage response through downregulation of ataxia telangiectasia mutated (ATM) kinase. PLoS One. 2011; 6:e25454. https://doi.org/10.1371/ journal.pone. 0025454 .

88. Humphreys KJ, McKinnon RA, Michael MZ. miR-18a inhibits CDC42 and plays a tumour suppressor role in colorectal cancer cells. PLoS One. 2014; 9:e112288. https:// doi.org/10.1371/journal.pone.0112288.

89. Kouzmenko AP, Takeyama K, Ito S, Furutani T, Sawatsubashi S, Maki A, Suzuki E, Kawasaki Y, Akiyama T, Tabata T, Kato S. Wnt/beta-catenin and estrogen signaling converge in vivo. J Biol Chem. 2004; 279:402558. https://doi.org/10.1074/jbc.C400331200.

90. Li L, Gu M, You B, Shi S, Shan Y, Bao L, You Y. Long non-coding RNA ROR promotes proliferation, migration and chemoresistance of nasopharyngeal carcinoma. Cancer Sci. 2016; 107:1215-22. https://doi.org/10.1111/cas.12989.

91. Zhang A, Zhou N, Huang J, Liu Q, Fukuda K, Ma D, Lu Z, Bai C, Watabe K, Mo YY. The human long non-coding RNARoR is a p53 repressor in response to DNA damage. Cell Res. 2013; 23:340-50. https://doi.org/10.1038/cr.2012.164.

92. Wang SH, Zhang MD, Wu XC, Weng MZ, Zhou D, Quan ZW. Overexpression of LncRNA-ROR predicts a poor outcome in gallbladder cancer patients and promotes the tumor cells proliferation, migration, and invasion. Tumour Biol. 2016; 37:12867-75. https://doi.org/10.1007/s13277016-5210-z.

93. Wang S, Liu F, Deng J, Cai X, Han J, Liu Q. Long Noncoding RNA ROR Regulates Proliferation, Invasion, and Stemness of Gastric Cancer Stem Cell. Cell Reprogram. 2016; 18:319-26. https://doi.org/10.1089/cell.2016.0001.

94. Guo F, Parker Kerrigan BC, Yang D, Hu L, Shmulevich I, Sood AK, Xue F, Zhang W. Post-transcriptional regulatory network of epithelial-to-mesenchymal and mesenchymalto-epithelial transitions. J Hematol Oncol. 2014; 7:19. https://doi.org/10.1186/1756-8722-7-19.

95. Xu C, Li M, Zhang L, Bi Y, Wang P, Li J, Jiang X. MicroRNA-205 suppresses the invasion and epithelialmesenchymal transition of human gastric cancer cells. Mol Med Rep. 2016; 13:4767-73. https://doi.org/10.3892/ mmr.2016.5118. 
96. Wang SH, Wu XC, Zhang MD, Weng MZ, Zhou D, Quan ZW. Long noncoding RNA H19 contributes to gallbladder cancer cell proliferation by modulated miR-194-5p targeting AKT2. Tumour Biol. 2016; 37:9721-30. https:// doi.org/10.1007/s13277-016-4852-1.

97. Li S, Yu Z, Chen SS, Li F, Lei CY, Chen XX, Bao JM, Luo Y, Lin GZ, Pang SY, Tan WL. The YAP1 oncogene contributes to bladder cancer cell proliferation and migration by regulating the $\mathrm{H} 19$ long noncoding RNA. Urol Oncol. 2015; 33:427 e1-10. https://doi.org/10.1016/j. urolonc.2015.06.003.

98. Jiang X, Yan Y, Hu M, Chen X, Wang Y, Dai Y, Wu D, Zhuang Z, Xia H. Increased level of H19 long noncoding RNA promotes invasion, angiogenesis, and stemness of glioblastoma cells. J Neurosurg. 2016; 124:129-36. https:// doi.org/10.3171/2014.12.JNS1426.

99. Liu L, Yang J, Zhu X, Li D, Lv Z, Zhang X. Long noncoding RNA H19 competitively binds miR-17-5p to regulate YES1 expression in thyroid cancer. FEBS J. 2016; 283:2326-39. https://doi.org/10.1111/febs.13741.

100. Liu G, Xiang T, Wu QF, Wang WX. Long Noncoding RNA H19-Derived miR-675 Enhances Proliferation and Invasion via RUNX1 in Gastric Cancer Cells. Oncol Res. 2016; 23:99-107. https://doi.org/10.3727/09650401 5X14496932933575.

101. Xia Z, Yan R, Duan F, Song C, Wang P, Wang K. Genetic Polymorphisms in Long Noncoding RNA H19 Are Associated With Susceptibility to Breast Cancer in Chinese Population. Medicine (Baltimore). 2016; 95:e2771. https:// doi.org/10.1097/MD.0000000000002771.

102. Zheng ZG, Xu H, Suo SS, Xu XL, Ni MW, Gu LH, Chen W, Wang LY, Zhao Y, Tian B, Hua YJ. The Essential Role of H19 Contributing to Cisplatin Resistance by Regulating Glutathione Metabolism in High-Grade Serous Ovarian Cancer. Sci Rep. 2016; 6:26093. https://doi.org/10.1038/ srep26093.

103. Wu KF, Liang WC, Feng L, Pang JX, Waye MM, Zhang JF, $\mathrm{Fu}$ WM. H19 mediates methotrexate resistance in colorectal cancer through activating Wnt/beta-catenin pathway. Exp Cell Res. 2017; 350:312-7. https://doi.org/10.1016/j. yexcr.2016.12.003.

104. Tsang WP, Kwok TT. Riboregulator H19 induction of MDR1-associated drug resistance in human hepatocellular carcinoma cells. Oncogene. 2007; 26:4877-81. https://doi. org/10.1038/sj.onc.1210266.

105. Wang Q, Cheng N, Li X, Pan H, Li C, Ren S, Su C, Cai W, Zhao C, Zhang L, Zhou C. Correlation of long non-coding RNA H19 expression with cisplatin-resistance and clinical outcome in lung adenocarcinoma. Oncotarget. 2017; 8:2558-67. https://doi.org/10.18632/oncotarget.13708.

106. Lu X, Wang ZC, Iglehart JD, Zhang X, Richardson AL. Predicting features of breast cancer with gene expression patterns. Breast Cancer Res Treat. 2008; 108:191-201. https://doi.org/10.1007/s10549-007-9596-6.

107. Oda E, Ohki R, Murasawa H, Nemoto J, Shibue T, Yamashita T, Tokino T, Taniguchi T, Tanaka N. Noxa, a BH3-only member of the Bcl-2 family and candidate mediator of p53-induced apoptosis. Science. 2000; 288:1053-8.

108. Cao B, Li M, Zha W, Zhao Q, Gu R, Liu L, Shi J, Zhou J, Zhou F, Wu X, Wu Z, Wang G, Aa J. Metabolomic approach to evaluating adriamycin pharmacodynamics and resistance in breast cancer cells. Metabolomics. 2013; 9:960-73. https://doi.org/10.1007/s11306-013-0517-X.

109. Zhang J, Wang Y, Zhen P, Luo X, Zhang C, Zhou L, Lu Y, Yang Y, Zhang W, Wan J. Genome-wide analysis of miRNA signature differentially expressed in doxorubicin-resistant and parental human hepatocellular carcinoma cell lines. PLoS One. 2013; 8:e54111. https://doi.org/10.1371/journal. pone.0054111.

110. Meijerman I, Beijnen JH, Schellens JH. Combined action and regulation of phase II enzymes and multidrug resistance proteins in multidrug resistance in cancer. Cancer Treat Rev. 2008; 34:505-20. https://doi.org/10.1016/j. ctrv.2008.03.002. 